\title{
Venturing into unknown territory: Strategic spatial planning in post-communist cities
}

Recent planning practice in post-communist cities indicates a growing interest in strategic spatial planning. In their search for new planning paradigms and more flexible approaches to city planning, municipalities in post-communist cities have embraced strategic planning as a way to involve residents, the business community and various stakeholders in defining a vision for the future. Drawing on the experience of six capital cities - Prague, St Petersburg, Vilnius, Sofia, Budapest and Riga - this article outlines the essential characteristics of the process (planning) and the product (a strategic plan). It establishes clear links between the strategic development process, its institutional framework and the hierarchical structure of goals, objectives and actions. Using a framework for strategic spatial planning in the context of rapid economic, social and governance change, the study evaluates the results of the process, focusing on "what" and "how" in the complex reality of planning. The framework applies the traditional strategic planning model, which establis- hes relationships between past, present and future to design alternative strategies for plan implementation, but in a much more unstable and unpredictable institutional environment. The research highlights the responsiveness of strategic planning to transition imperatives and its ability to define contextually appropriate multidimensional strategies for the spatial development of post-communist cities.

Keywords: strategic planning, transition, post-communist cities, planning, public participation, sustainable cities 


\section{Introduction}

Recent planning experiences in post-communist cities indicate a growing interest in strategic spatial planning. Most capital cities from the Baltics to the Balkans have gone through a strategic development process in the last 10 years with varied degrees of success (Maier, 2000; Tsenkova, 2007a). A number of secondary cities have replicated the process, giving an impetus to a range of strategic planning politics. Although strategic planning is not necessarily embedded in the planning legislation, it appears to provide a much-needed link between traditional comprehensive land-use planning and fiscal and financial planning carried out by municipal bureaucracies (Nedovic-Budic, 2001; Tosics, 2003). In their search for new planning paradigms and more flexible approaches to city planning, municipalities in post-communist cities have embraced strategic planning as a way to involve residents, the business community and various stakeholders in defining a vision for the future. Experiments with strategic spatial planning in several countries such as the Czech Republic, Lithuania and Poland have led to the institutionalisation of the approach in mainstream planning practice. Strategic spatial planning has evolved as a parallel instrument to statutory land-use planning, master planning and regional planning. Regional planning imposed by European Union guidelines is perceived as a bureaucratic budget-enlargement exercise with limited comprehensiveness and public involvement.

This article explores challenges and opportunities for strategic spatial planning in post-communist cities. Drawing on the experience of six capital cities - Prague, St Petersburg, Vilnius, Sofia, Budapest and Riga - it outlines the essential characteristics of the process (planning) and the product (a strategic plan). It establishes clear links between the strategic development process, its institutional framework and the hierarchical structure of goals, objectives and actions. The case studies provide important insights for planning practice in the context of rapid economic, social and institutional change. The research highlights the responsiveness of the model to transition imperatives and its ability to define contextually appropriate multidimensional strategies for the spatial development of post-communist cities.

The methodology for this research draws on content analysis of policy documents and secondary sources of analytical information pertinent to the strategic planning process in the cities under review. These methods are supplemented by personal interviews with major stakeholders involved in the strategic planning processes over a period of 3 years as well as personal observation and strategy formulation in Sofia.

\section{Strategic spatial planning in Europe}

Strategic spatial planning is an active "social process through which local communities respond to internal and external challenges with respect to the management of local environments" (Healey et al., 1997: 293). It builds on and transforms established ways of doing things (institutional relations) and accepted ways of looking at things (policy agendas) in order to create locally new institutional capacities for influencing the future (Albrechts et al., 2003). Western Europe provides a distinctive institutional environment for strategic spatial planning, particularly given the ideological acceptance of public intervention for the common good (Healey et al., 1999). Studies indicate that strategic spatial planning is well positioned to address the economic, social and environmental dimensions of urban and regional change through locally articulated strategies that involve a wide range of partners in policy formulation and realisation (Healey et al., 1997; Albrechts, 2006). The mobilisation of this wider coalition of actors and institutions - upper-level government, non-government organisations (NGOs) and business interests - in support of a city is an essential part of the process. However, strategic planning efforts are demanding in terms of institutionalisation; they require extensive consultation to establish legitimacy and representation, and to ensure diversity of input (Bryson et al., 1986; Salet \& Faludi, 2000). There has been much debate about strategic spatial planning and its links to "place making" and a proactive "entrepreneurial" style of governance (Newman \& Thornley, 1996; Faludi, 2004). Much of the discussion has centred on processes, on mobilisation of stakeholders and development of collective power, and on "top down" vs. "bottom up" approaches (Baker, 2001). Other studies have explored the selectivity of strategic plans (Maier, 2000) or the internal inconsistencies in strategic planning documents (Healey et al., 1999).

The advantages of strategic spatial planning are usually associated with the process itself. It provides the means for wider consideration of alternatives, stimulation of discussion, creation of a framework for inclusive decision-making and the establishment of expert policy-making bodies to enrich local implementation capacity (Radford, 1980; Healey et al., 1999). Michael Bruton and David Nicholson (1985) emphasise the advantage of a hierarchical arrangement in strategic planning, which allows a comprehensive but generalised overview of issues to be established at the top level to be further developed into more detailed policies and implementation strategies at the lower levels. Some of the disadvantages are usually associated with the lack of clear links between strategy and implementation, particularly from the higher level of decision-making to the operational levels. The adequacy of resources for the planning process and its implementation are a significant challenge, often undermining the validity of the process itself (Baker, 2001). 


\section{Spatial planning in post-communist cities: Managing the triple transition}

The literature on strategic planning, or planning in general, in post-communist cities is very limited. In constructing a new planning system, these countries do not have a single model to follow. What is clear is that the new regulatory form of planning under the market system is an alien concept to the communist planning tradition, in which the plan operated more as a horizontal spatial system bringing together sectoral public investment programs (Thomas, 1998). Most commentators on planning challenges in the post-communist era have focused on the links between land reforms, privatisation/restitution of real estate and the development of planning institutions (Bertaud \& Renaud, 1997; Golubchikov, 2004). Studies have indicated that the new market-based regimes do not necessarily have a coherent ideology, but have instead adopted a laissez-faire approach to planning and public policy, thus creating more uneven urban development (Jaakson, 2000). The traditional tools of land-use planning, sectoral infrastructure planning and financial management - a powerful communist legacy - are still imbedded in planning legislation and planning practice (Bertaud \& Renaud, 1997; Tsenkova, 2007b). Municipal planning departments operate in isolation, maintaining the working etiquette of a "closed office", and experiences with public consultation in the planning process tend to be limited. These are significant factors that influence the emerging planning system in general and the implementation of strategic planning in particular.

It is important to position the post-communist experience with strategic spatial planning in the framework of the overall institutional transformation on the one hand, and in the context of rapid economic and political system change on the other. This undeniable complexity creates unique challenges for urban planning (see Tsenkova, 2008 for further discussion). The urban system serves as the primary channel linking the national economy to the system of global cities (Buck et al., 2005). Viewing development through the urban lens, the approach explicitly links the changes in the external environment (national and global), which are much more dramatic and revolutionary, to changes in the internal environment (the urban system and the city itself) by emphasising the nature of the ongoing transformation, reciprocity and diversity. The transformations are associated with three aspects of the transition process that are particularly important for post-communist cities: the transition to democracy (systemic political change), to a market economy (systemic economic change) and to decentralised systems of local democratic governance (World Bank, 2000; Tsenkova, 2006).
Although these interrelated aspects of the post-communist transition have been explored at the national level, very few studies have acknowledged their impact on post-communist cities (Adair et al., 1999; Hamilton et al., 2005; Tsenkova, 2006). The triple transition sets the framework for specific changes in four interrelated domains identified in Table 1. Strategic spatial planning responds to the need to guide city-level transformation in the economic, social, institutional and spatial structure, thus shaping the future trajectory of the urban system. One way of capturing the multilayered nature of transformations in the four domains is to compare the main characteristics of the post-communist and communist city. The main point of departure is perhaps the ideal model of a communist city with its salient features discussed in the literature (see Andrusz et al., 1996; Hamilton et al., 2005). Notwithstanding country-specific differences, however, one can distinguish the major pattern of change in the urban economy, society, governance system and spatial adjustment of production and consumption spaces defining the post-communist city. Although these characteristics are admittedly very broad, they nevertheless suggest the direction of the urban transformation.

Regarding economic change, the market-based restructuring of urban systems responds to an integration process in the global economic hierarchy of cities. The economic deregulation and opening up of previously sheltered markets and the rapid adjustment of industries, services and other economic activities has had important effects on the direction of change and on specialisation in cities' economic bases (Tsenkova, 2008). Empirical evidence suggests that the transition from industrial to service-oriented urban economies has increased diversification and competitiveness (Van Kempen et al., 2005). Individual urban areas have undergone differentiated development, with some losing economic attractiveness and others gaining it.

Social change is related to the structural adjustment of highly urbanised societies in which the communist legacy of centrally directed urbanisation driven by industrial growth has powerful consequences. Highly urbanised economic systems across the region are much more vulnerable to external shocks and, given the relatively low per capita income, are difficult to maintain. Over-industrialised cities have been affected by the massive closures of unproductive state enterprises. Unemployment and poverty have escalated (World Bank, 2000). On the other hand, some countries with low levels of urbanisation have experienced rapid migration to urban areas and rising urban poverty. In the context of fiscal austerity and a less generous welfare state, income inequalities and social polarisation have become one of the most significant urban challenges (Buckley \& Mini, 2000). 
Regarding urban governance, the transition to democracy is manifested in local politics. Post-communist cities have a variety of political structures ranging from single-tier to multi-tier governments. In local government elections, parties negotiate representation to create multiparty coalitions. Council members often broker different political interests, making consensus difficult, but are potentially more open to influence from city residents compared to communist times (Tsenkova, 2007a). Although democratically elected local governments have acquired critical powers in planning and city management, limited budgets have made it very difficult to deliver essential services such as public transport, waste management and water supply (European Commission, 2007).

In spatial terms, the transition process has facilitated two distinct patterns of spatial restructuring: decentralisation of pro- duction/consumption spaces and spatial inequality (Tsenkova, 2008). Decentralisation trends have been more pronounced for new retail and industrial development. Suburban locations have offered cheaper land, access to major transport networks and recognised economies of scale for new office parks (see Stanilov, 2007). Considerable growth in the construction of single-family homes and other low-rise housing provided by decentralised suppliers, often on the urban periphery, has created a new residential landscape. The development pressure on traditional central areas has continued with the cluster of service, financial and highly profitable urban functions replacing economically less viable activities such as obsolete industries and substandard housing (Bater, 2001; Tsenkova, 2006). This post-communist restructuring of urban spaces is often associated with speculative private-sector development for affluent consumers, corporations and multinational companies.

Table 1: The trajectory of urban change in post-communist cities.

\begin{tabular}{|c|c|c|}
\hline \multicolumn{3}{|c|}{$\begin{array}{l}\text { Major drivers of urban change: transition to democracy (systemic political change), market economy (systemic economic change) and a } \\
\text { decentralised system of local governance }\end{array}$} \\
\hline Domain & $\begin{array}{l}\text { The "communist" city: } \\
\text { Main characteristics }\end{array}$ & $\begin{array}{l}\text { The "post-communist" city: } \\
\text { Main characteristics }\end{array}$ \\
\hline National urban system & $\begin{array}{l}\text { - Centrally planned population growth, invest- } \\
\text { ment, economic development, job creation; } \\
\text { - Stable increases in the level of urbanisation, } \\
\text { sustained concentration in large metropolitan } \\
\text { areas, economies of scale in production. }\end{array}$ & $\begin{array}{l}\text { Market-based restructuring of the urban } \\
\text { system, integration in the global economic } \\
\text { hierarchy of cities, service-led growth, core } \\
\text { vs. periphery; } \\
\text { - Selective growth of cities, population decline } \\
\text { in many urban centres. }\end{array}$ \\
\hline Urban economic change & $\begin{array}{l}\text { Macroeconomic control through central plan- } \\
\text { ning, regulation, and collective bargaining, } \\
\text { control of markets through income and price } \\
\text { policies. }\end{array}$ & $\begin{array}{l}\text { Deregulation of markets, laissez faire ap- } \\
\text { proaches to economic development, growing } \\
\text { competition, decline of manufacturing, un- } \\
\text { employment, opening up sheltered markets. }\end{array}$ \\
\hline Urban social change & $\begin{array}{l}\text { - Stronger welfare state, universal subsidies, } \\
\text { moderate (controlled) urban growth, relative- } \\
\text { ly homogeneous social structure, egalitarian } \\
\text { income distribution. }\end{array}$ & $\begin{array}{l}\text { - Retrenchment of the welfare state, socially } \\
\text { polarised societies, poverty, marginalisation, } \\
\text { declining and aging population, high eco- } \\
\text { nomic dependency. }\end{array}$ \\
\hline \multirow{2}{*}{$\begin{array}{l}\text { Change in urban governance } \\
\text { and provision of urban services }\end{array}$} & $\begin{array}{l}\text { Dominated by central government deci- } \\
\text { sion-making, appointed officials, little au- } \\
\text { tonomy; }\end{array}$ & \multirow{2}{*}{$\begin{array}{l}\text { - Democratically elected, decentralised, frag- } \\
\text { mented structure, fiscally dependent on } \\
\text { central transfers, entrepreneurial approaches } \\
\text { to planning and city marketing; } \\
\text { - Privatisation and marketisation in the provi- } \\
\text { sion of urban services, unfunded social man- } \\
\text { dates, growing inequalities in provision of } \\
\text { water, sewer and public transport. }\end{array}$} \\
\hline & $\begin{array}{l}\text { largely funded by central governments, uni- } \\
\text { versal access to education and healthcare, } \\
\text { investment in water and sewer networks, } \\
\text { strong emphasis on public transport. }\end{array}$ & \\
\hline \multirow{2}{*}{$\begin{array}{l}\text { Urban spatial change: } \\
\text { production consumption }\end{array}$} & $\begin{array}{l}\text { Dominated by manufacturing and responsive } \\
\text { to the needs of large-scale state producers, } \\
\text { located in urban areas according to planning } \\
\text { norms; }\end{array}$ & $\begin{array}{l}\text { - Growing percentage of obsolete manufactur- } \\
\text { ing facilities, new spaces for private small } \\
\text { and medium production, suburbanisation of } \\
\text { offices and retail; }\end{array}$ \\
\hline & $\begin{array}{l}\text { Relatively uniform, social housing provision } \\
\text { allocated by state institutions, universally } \\
\text { affordable, built according to planning } \\
\text { norms, mix of tenure types. }\end{array}$ & $\begin{array}{l}\text { - Increasingly polarised social areas and hous- } \\
\text { ing markets, gentrified housing enclaves vs. } \\
\text { problematic housing estates, predominantly } \\
\text { owner-occupied. }\end{array}$ \\
\hline
\end{tabular}

Source: Adapted from Sasha Tsenkova (2006). 


\section{Framework for spatial strategic planning in post-communist cities}

Planning for the uncertain future is a very important aspect of current post-communist politics. Although there are obvious differences in the way the three aspects of the transition process (the transition to democracy, a market economy and democratic governance) affect different post-communist cities, they set a very unique context for strategic planning. The magnitude of change, both in the external and internal environment, as well as the turbulence affecting planning institutions, is much more significant. The framework presented in Figure 1 applies the standard strategic planning model, which establishes relationships between past, present and future to design alternative strategies for plan implementation (Tsenkova, 2007b). Linking the past with the present is guided by exploration of "where are we now?" whereas linking the present to the future is guided by "where do we want to be?" (Abott, 2005).
The future reflects a community vision usually developed with some degree of consultation with major stakeholders to build consensus and ensure shared ownership. The strategic planning process explores various alternative futures and attempts to incorporate the most appropriate one into the strategic plan. Selecting priorities and designing alternative courses of action essentially responds to the fundamental question "how do we get there?" (Bryson et al., 1986; Healey et al., 1997). This formulation of action plans implies a good understanding of trends, patterns of change in the natural, built, organisational and social environment, and clear definition of ways to influence the implementation process (Salet \& Faludi, 2000).

The framework recognises that, as a forward-looking activity, planning driven by the future is selective in its analysis of elements in the past and present (Friedman, 1987). Often planners assume that natural, economic, social and political processes that have linked events in the past will continue to link the present to the future. Knowledge of the future in planning

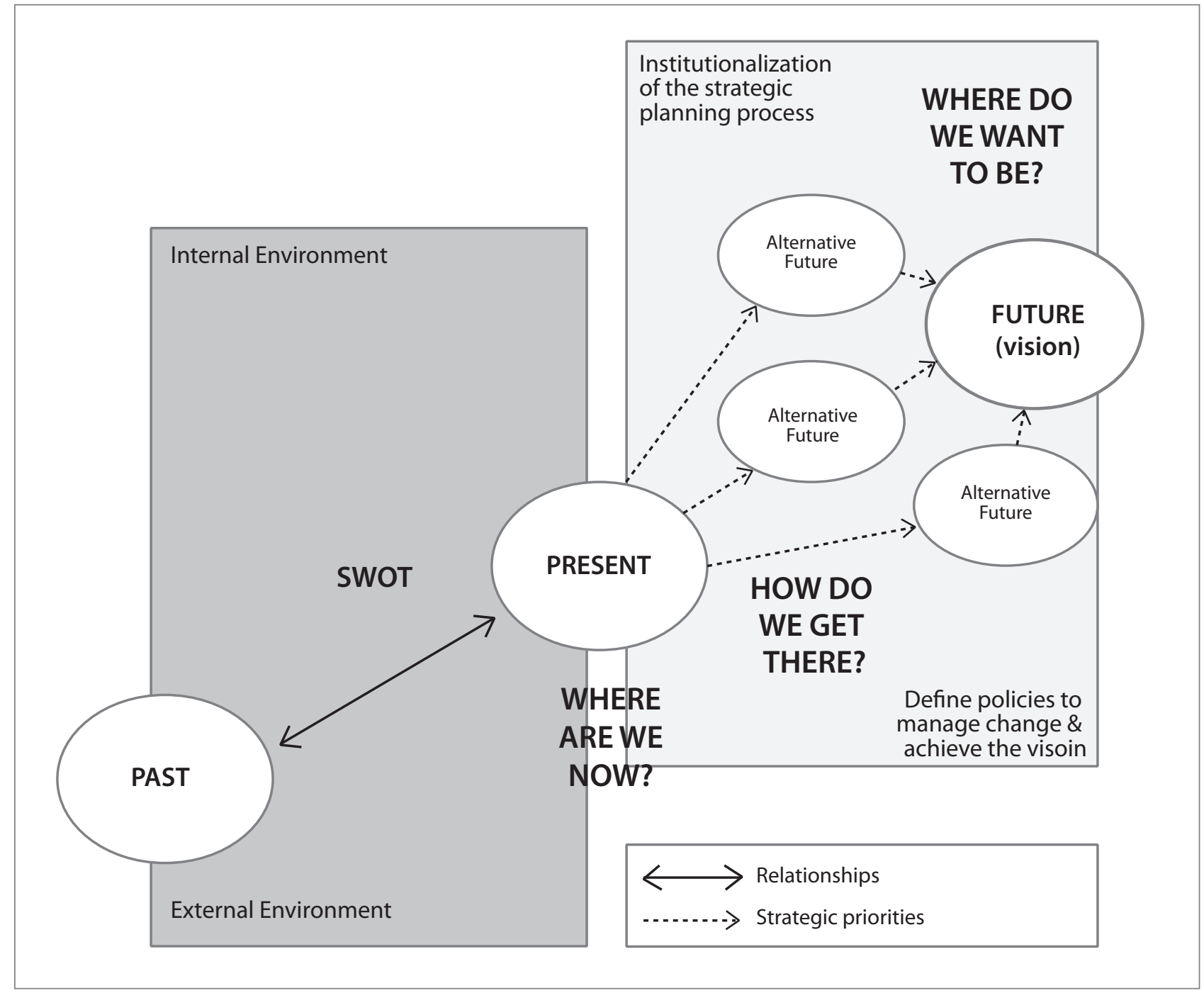

Figure 1: Strategic planning in the context of transition (source: adapted from Tsenkova, 2007b). 
terms is often lacking, and uncertainty both within the internal and external environment is a major constraint (Abott, 2005). In addition, the planning process is embedded in the external environment; these contextual influences have a critical way of influencing both the decision-making process and the choice of strategic priorities. The conceptual framework distinguishes the following stages of the strategic planning process: Strengths, Weaknesses, Opportunities and Threats (SWOT) analysis, selection of key issues/priorities and the development of goals, objectives and strategies in key priority areas (Kaufman \& Jacobs, 1987). Because the institutionalisation of the process is an important element, the framework highlights the significance of formal arenas (the strategic planning team and key decision-makers) in presenting the strengths and weaknesses of the present and in articulating strategic actions in the future (Albrechts et al., 2001).

It should be noted that the framework is designed to accommodate some of the unique challenges for strategic planning in post-communist cities. In particular, the changes in the external environment are much more dramatic and revolutionary in nature when associated with the transition to democracy and a market economy (Thomas, 1998; Buckley \& Tsenkova, 2001). Despite the diversity in outcomes generated by this dual transition across countries and cities, what is clear is that the links between the past and the present are less explicit and the ability to define the future is less promising. Another less-known aspect of the transition - "the quiet revolution" associated with decentralisation and devolution of power and responsibility to local governments - significantly affects the scope of the action plans (Tsenkova, 2006). A new intergovernmental institutional setup and fiscal central/local relations require mobilisation of wider support for the implementation of strategic plans (Maier, 2000; Tosics, 2003). Uncertainty about choices of governments, organisations, businesses and individuals in the turbulent environment of post-communist cities makes the implementation of alternative futures much more difficult. The internal environment is also in a state of flux, reflected in the rapid adjustment of the physical, economic, social and political structure of the city itself (Nedovic-Budic, 2001).

The framework is applied to the analysis of major stages/phases in the strategic spatial planning process in the case studies. It provides insights into the development of institutional capacity/arenas able to initiate and support the process. This institutionalisation is then related to the identification of major milestones in the strategic planning processes and content analysis of major thematic blocks of the plans.

\section{The strategic planning process}

The development of strategic plans in the capital cities of post-communist Europe started in the mid-1990s, often with some donor assistance. ${ }^{[1]}$ The broad goal of these initiatives is to generate sustainable, long-term benefits for city residents while enhancing the competitiveness of the local economies and the development of a democratic and self-reliant municipal management system. The strategic plans promote the creation of a vision for the future development of the city with clearly defined goals, objectives and actions for priority areas. These are long-term policy documents with a timeframe of 10 to 15 years. Budapest is the only exception, advocating a vision for the next 30 to 40 years. ${ }^{[2]}$ The strategic planning process is often divided into the four or five phases identified in Table 2 . The process appears to be quite lengthy, particularly in the case of Budapest, and includes a series of iterations to validate strategic priorities, objectives and appropriate course of action. Public consultation and various forms of expert and city management input are channelled through the process to build consensus on different development scenarios and drafts of the strategic plan.

In the case of the six strategic planning processes reviewed in this paper, the following pattern can be identified:

- Process organisation and analytical work. Following agreement on the strategic planning process, the internal and external environment is usually analytically scanned. The focus tends to be on issues pertaining to the city's competitive advantage, economy, social and spatial changes, and sectoral issues related to infrastructure, housing and real-estate development. A SWOT analysis and identification of key issues and priorities is carried out (Prague, Vilnius, St Petersburg and Sofia).

- Formulation of a community vision. The SWOT analysis assists in the definition of key issues and priorities and the formulation of a vision, often with broad stakeholder input (Riga, Vilnius and Sofia). Interim endorsement of the vision by senior city management is often required at this stage.

- Formulation of strategic plans. The first drafts incorporate a summary of the SWOT analysis and identify the hierarchical system of goals, strategic objectives and priorities for action. Building consensus among city residents, stakeholders and development partners on key objectives and priorities further refines the strategic plan. Public input is facilitated through a variety of means: conferences (Budapest, St Petersburg and Vilnius), surveys and public meetings, roundtables, and open houses ${ }^{[3]}$ (Riga, Sofia and Prague).

- Revisions, validation, development of action and implementation plans. A second (in the case of Budapest, fourth and fifth) draft strategy document and action program matrix with measurable objectives supporting the major goals is prepared and circulated to key stakeholders for review. At this stage, some cities opt for expert review 
and input (St Petersburg, Sofia and Prague) as opposed to general consultation with the public (Riga and Vilnius). The critical difference is also in the action matrix embedded in the strategic plan. Prague, Vilnius and to some extent Sofia have identified a specific institution responsible for implementation of actions as well as corresponding budgets, which makes the task of monitoring more manageable.

- Approval and implementation of strategic plans. The strategic planning process concludes with the endorsement of the Strategic Plan by the Municipal Council, although the documents suggest that subsequent revisions are expected and the actual implementation process might augment the choice of strategic priorities.

It is important to note that the strategic plans as long-term city development visions have an important influence over the more traditional land-use / master-planning documents (Sofia and Prague) as well as regional strategies (Prague, Sofia and Vilnius) and other more operational urban-management tools such as 5- to 7-year investment programs (Budapest and Vilnius). In Riga, the long-term development strategy is expected to function as an umbrella document for the entire City Development Plan (2006-2018), being the most important policy document of the Riga City Council and a tool for city management and development control.

\subsection{Institutionalisation of the process: Design of arenas}

Institution-building (i.e., designing arenas) is initiated early in the strategic planning process. In most of the cases, the lead institution is based within the city administration, although Budapest and St Petersburg are exceptions (see Table 2). The formal arenas are established to lead the thematic work associated with the SWOT analysis and to manage the input of various stakeholders into the strategic planning process (Tsenkova, 2002). The key decision-makers typically include city mayors, councillors (local politicians), senior management and members of the lead strategic plan institution (or department). ${ }^{[4]}$

From the very start, these formal arenas seem to be complemented by the informal participation of experts and institutional representatives from central government ministries, agencies, non-governmental organisations and academic institutions. This somewhat hierarchical structure is legitimised through the strategy process and expanded during subsequent rounds of public consultation (workshops, conferences, open houses, etc.). For example, the engagement process included assignment of experts to "task-specific" circles aligned with the thematic areas of the Sofia Strategy, whereas in St Petersburg the draft action plan was prepared by 12 thematic committees.
The consolidation of public and stakeholder input as well as feedback from the municipal administration is often done by consultants (Budapest, St Petersburg, Sofia and Riga), although the results are vetted by key decision-makers (for further discussion, see Tsenkova, 2007a). Although the implementation is vested with the city administration, in several cases the lead strategic planning institution (Vilnius, Riga and Prague) continues to exist beyond the approval date and assumes the role of a monitoring agency.

\subsection{Public participation}

This is perhaps the most challenging part of the strategic planning processes, which marks a radical departure from planning under communism. Various strategies are incorporated in the cities under review, ranging from more to less inclusive ${ }^{[5]}$ Riga, for example, has chosen a very open and democratic process to formulate its vision. A public involvement campaign called "I Do Riga" was launched in April 2004 including mail-out questionnaires to every household, street advertisements, working breakfasts and open discussion forums with experts. ${ }^{[6]}$ Within 3 weeks it generated more than 12,000 written opinions, excluding those of the experts. The second round of public consultation in December 2004 on the draft strategy was done through an 8-week exhibition and thematic workshops that resulted in close to 5,000 different submissions (Riga City Council, 2005).

The approach in Vilnius includes a mix of surveys (of experts, residents and municipal officials), working breakfasts, seminars and conferences soliciting feedback on the Vilnius City Strategic Plan. The leading institution presented a vision and a plan to a number of stakeholders to consolidate different opinions, but it does not seem that residents were actually involved in the formulation of objectives and action plans. ${ }^{[7]}$ Retaining more control over the process certainly made it more manageable and allowed its completion within one year. In St Petersburg, and to some extent in Budapest, the public participation process was more formal, mostly targeting the expert community. In St Petersburg, the strategic objectives were presented to a conference attended by 400 people. The strategic plan was accepted part by part at a final conference in 1997, which had 15 sectional meetings attended by 900 people.

In Budapest, each draft of the strategic plan was presented to an expert audience with efforts to engage local politicians. ${ }^{[8]}$ The spring of 2002 marked a period of wider dissemination of the concept through the City Forum of Budapest, in which at least 150 persons participated. In Sofia, close to 200 people, representing a variety of institutions, were engaged in roundtable discussions, voting and selection of priorities. Facilitated discussions, "dotmocracy" voting and reporting of 


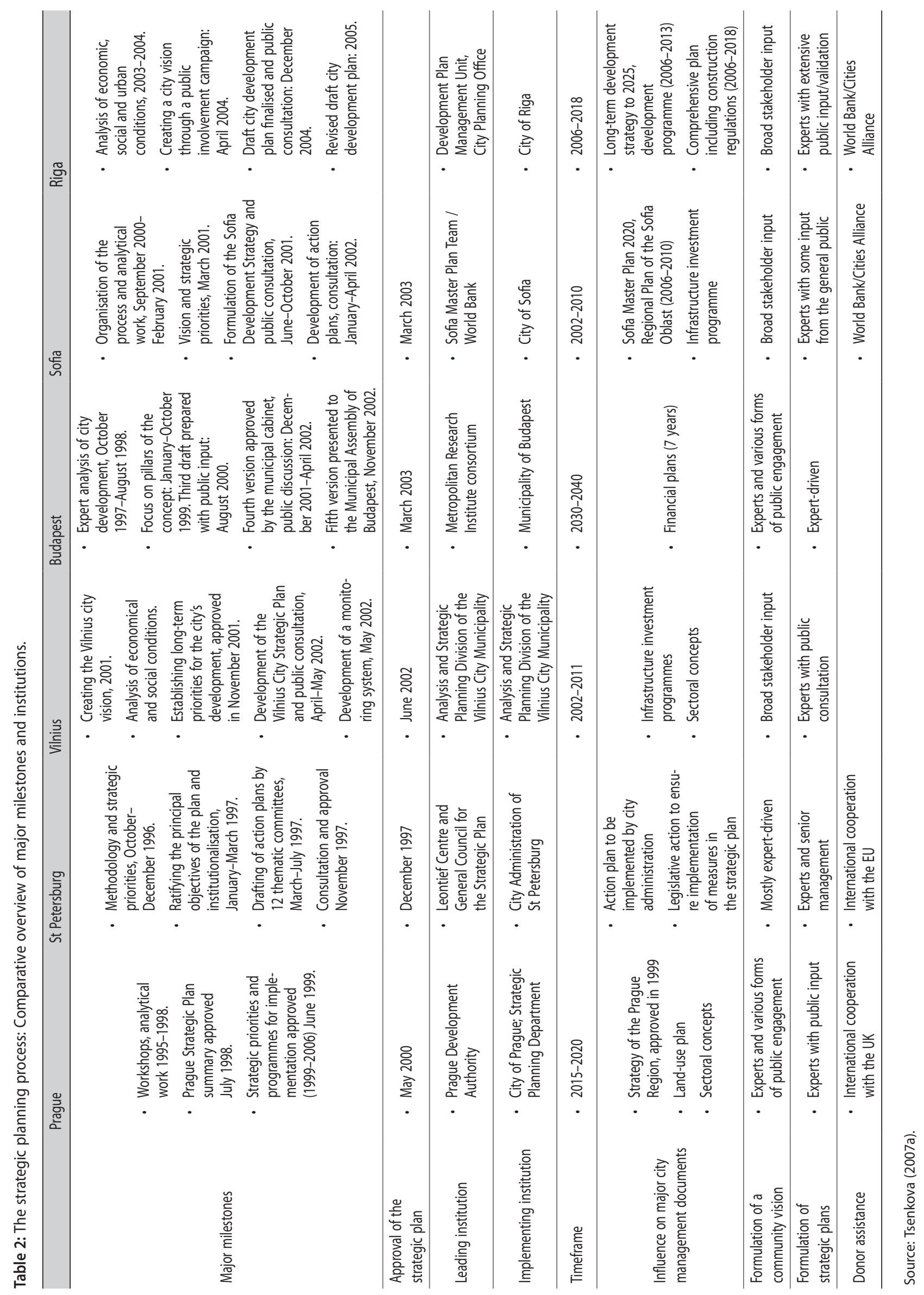



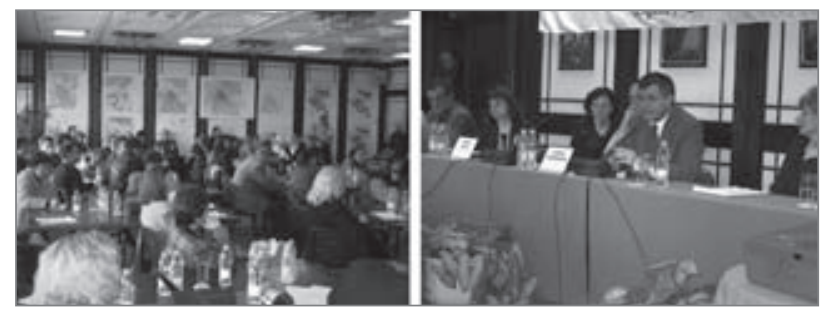

Figure 2: Public consultation and presentation of priorities in Sofia's strategic planning process supported by the World Bank (photo: Sasha Tsenkova).

results ensured that different views were taken into account and the process was transparent. The participants were brought together for a second round of consultation on priorities and actions. Facilitated discussions in eight "task-specific" circles engaged 110 experts to build consensus on Sofia's strategic action plan. Leaders of the "task-specific" circles presented their recommendations to the mayor and deputy mayors (see Figure 2). In addition, two representative surveys were carried out to incorporate the views of businesses and citizens (Zeijlon et al., 2002). The consultations generated a significant level of interest and, given the lack of tradition in public involvement, were perceived to be successful in changing the traditional hierarchical relationships and lines of communication among local government, NGOs and citizens. Overall, despite the best intentions, it is difficult to achieve consensus and to broker different interests, particularly at the level of action plans and budgets. ${ }^{[9]}$

\section{Plan content: Visions for sustainable cities}

\subsection{Visions}

The visionary approach is a more flexible way to deal with an uncertain world. Visions set the broad outlines of a strategy, while leaving the specific details to be worked out (Mintzberg, 1994). In the post-communist context of uncertainty in the economic, political and social domains, the visions need to be connected to the present with a good understanding of the forces at work determining possible future alternatives. Although this process is no doubt very challenging, the city visions advanced in the strategic plans of the six cities demonstrate an effort to position them on the European stage of prosperous and attractive places. Riga is promoted as a city that offers opportunities for everyone, a convenient and comfortable place to live, a city that is metropolitan, diverse and efficiently managed. The vision statement of Vilnius speaks of the city's confidence and recently found prosperity: "Vilnius - The capital of Lithuania, the most modern city in Central and Eastern Europe, an international centre of politics, business, science and culture" (Vilnius City Municipality's
Administration, 2003: 2). St Petersburg's vision also promotes the city as Russias gateway to Europe, a cultural capital with an open economy that offers sustained improvement in the quality of life for its residents (see Figure 3). In a similar fashion, Sofia's vision statement portrays the city as the "capital of the Balkans, a city with a competitive economy and sustainable economic growth, ... with high quality of life, attractive for businesses, residents and tourists" (Zeijlon et al., 2002: 5). These city visions demonstrate a strong emphasis on competitiveness, economic growth and efforts to improve the quality of life through improvement of infrastructure, housing, transport and education. These city visions demonstrate a strong emphasis on competitiveness, economic growth and efforts to improve the quality of life through improvement of infrastructure, housing, transport and education.

\subsection{Thematic blocks of the strategic plans}

Notwithstanding the distinct features of each city and its economic, natural, social and cultural potential, several thematic blocks can be discerned in the hierarchical structure of goals, objectives and strategic priorities of the strategic plans: competitiveness, economy, society and urban environment. Although there is no doubt a fair amount of overlap with respect to the challenges that need to be addressed and priority actions, the plans tend to maintain this broad thematic classification in their structure. The interrelationships between the thematic blocks are perhaps best illustrated in Riga's presentation of strategic priority goals in Figure 4.

\subsection{Strategic objectives and actions}

The strategic plans articulate a variety of goals, strategic objectives and specific actions. The goals and objectives build upon strengths and opportunities identified in the SWOT analysis and establish the framework for strategic and operational decision-making. The matrix in Table 3 provides a comparison of the strategic plans of Prague, Vilnius, Riga, Sofia and St Petersburg. The Budapest Strategic Development Concept from 2003 was excluded from this analysis because it consists of eight strategic aims, each containing three to seven broad aims (39 altogether), which are further divided into specific aims. At the risk of oversimplifying the diversity of plan content, the analysis will focus on the similarities in the choices of goals and strategic objectives, as opposed to the nuances and/ or differences. Perhaps the similarities are due to the common legacy in post-communist cities and the impact of multiple transitions (to a market economy, democracy and pluralistic governance) discussed earlier.

In the economic realm, the focus is on accelerating growth in the local economy while addressing the dual challenges 
of stagnating labour markets and the shift to service-based economies (or knowledge-based in Vilnius). City leadership is expected to facilitate private-sector growth through more aggressive marketing of the city to national and international investors and a wider dissemination strategy for business and real-estate investment opportunities. The emphasis on place promotion (the dissemination of appropriate information about the main resources, products, spaces and services) and on "inward investment" strategies in the plans for Sofia, Vilnius, Prague and St Petersburg is particularly strong. The strategic priorities in the economic theme target development of skills and knowledge (Sofia, Vilnius and Riga), as well as existing industrial capacity (St Petersburg and Riga) to define the competitiveness of the local economy and its ability to attract new economic activities. In the economic adjustment process, the challenge and the opportunity for these cities is to create a climate that fosters restructuring and modernisation of the economy and contributes to equitable growth. The economic component of the strategic plans is closely linked to priorities to sustain the economic position of cities (Prague, Vilnius, St Petersburg and Sofia).

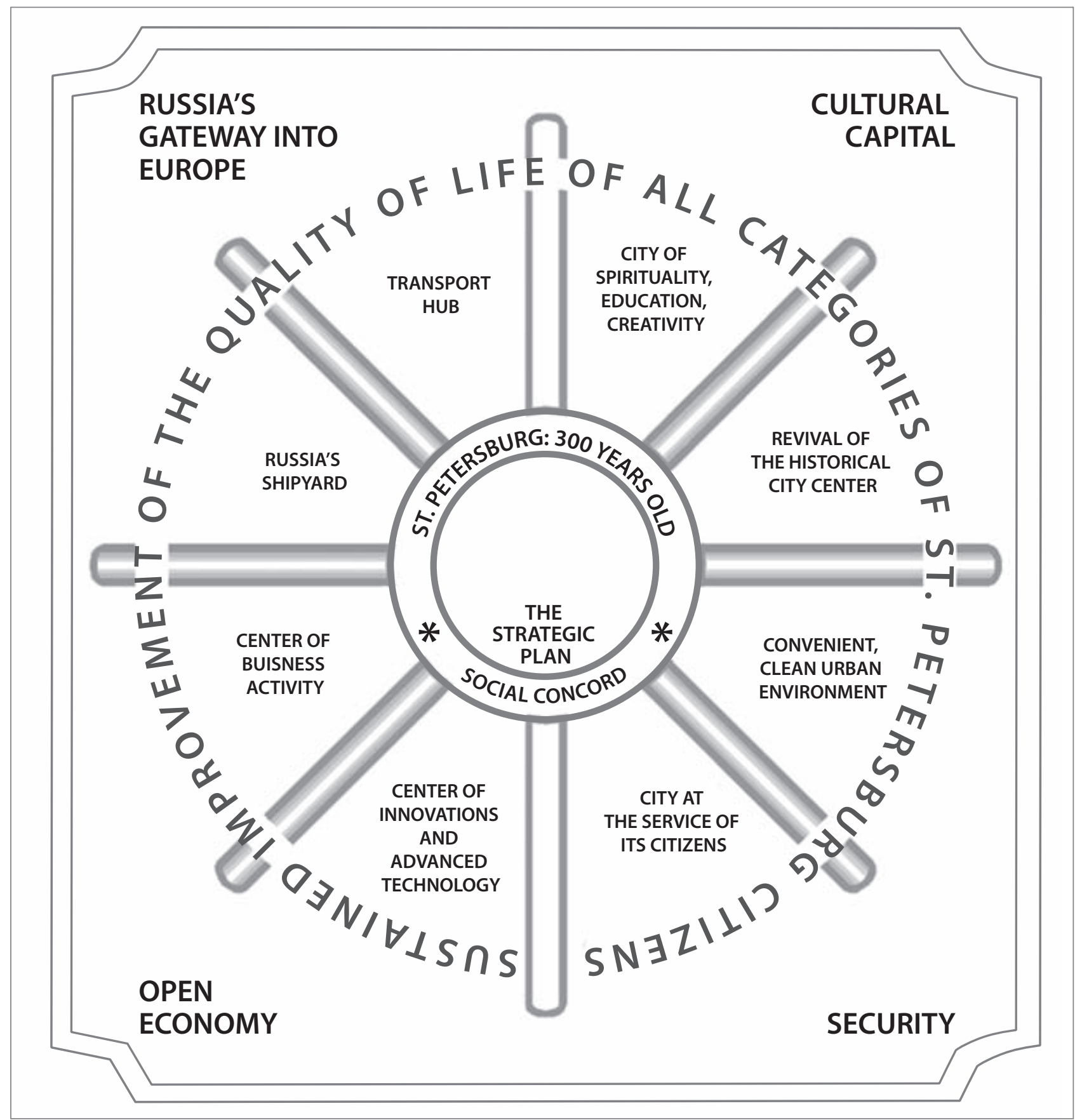

Figure 3: St Petersburg vision (source: General Council for St Petersburg, 1998). 
Although the SWOT analysis emphasises the high concentration of business headquarters and highly skilled labour force (see, e.g., Egedy \& Kovács, 2010) as well as a relatively high quality of life, the plans highlight the importance of urgent actions to improve the city's infrastructure (Riga and Vilnius) and urban management (Prague and Sofia) to sustain competitiveness. Other priorities relate to a more favourable business climate (St Petersburg) and city marketing (Prague and Vilnius).

In the social realm, issues of major concern include rising business and living costs, inadequate quality of life in existing housing areas, access to jobs, retail and recreation. The plans attempt to address these challenges through a particular emphasis on the improvement of social services (Sofia), investment in education (Riga, Vilnius and St Petersburg) and general action to improve opportunities for local residents (Prague).

Correspondingly, the urban structure component of the strategic plans emphasises the importance of the following objec- tives: a) investing in infrastructure to improve the quality of the services provided (Prague, Vilnius, Sofia and St Petersburg); b) creating a balanced, polycentric spatial structure to enhance sustainable opportunities (Prague and Sofia; see, e.g.,

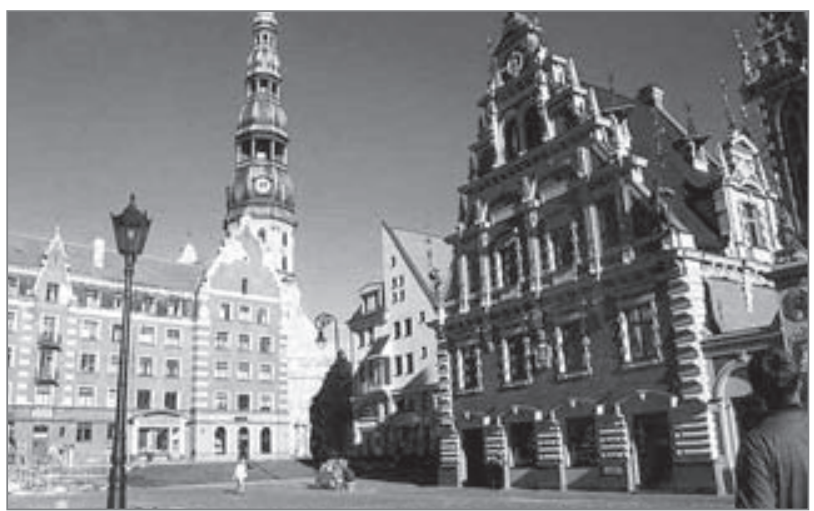

Figure 5: Riga's strategic plan aims for sustainable growth and development while tackling the revitalisation of Soviet-era residential districts and its historic core (photo: Sasha Tsenkova).

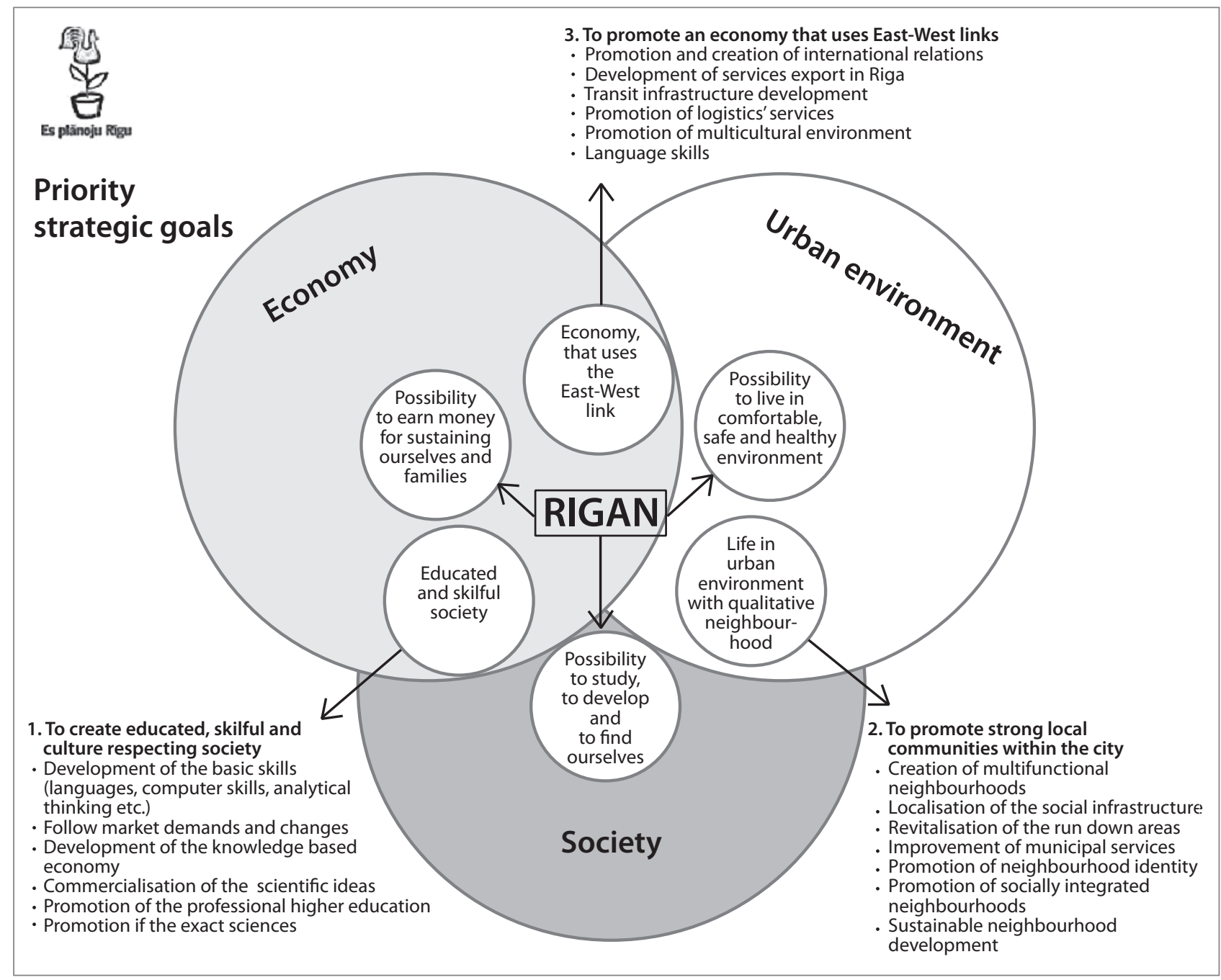

Figure 4: Riga City Development Plan strategic goals (source: Riga City Council, 2005). 
Table 3: Matrix of themes, goals and priorities in the strategic plans.

\begin{tabular}{|c|c|c|c|}
\hline & Prague & St Petersburg & Vilnius \\
\hline Major goals/priorities & $\begin{array}{l}\text { - Become a successful and competitive } \\
\text { city with a prosperous economy } \\
\text { - Improve quality of life and become } \\
\text { an attractive and well-balanced community } \\
\text { - Create a high-quality urban environment } \\
\text { while respecting sustainable } \\
\text { development; modernise transport } \\
\text { infrastructure } \\
\text { - Improve the city's management and } \\
\text { administration }\end{array}$ & $\begin{array}{l}\text { - Create a favourable living environment } \\
\text { - Create a favourable cultural and } \\
\text { industrial environment } \\
\text { - Integrate the city into the world } \\
\text { economy }\end{array}$ & $\begin{array}{l}\text { - Increase the international } \\
\text { competitiveness of Vilnius } \\
\text { - Develop a new economy } \\
\text { - Create an advanced society } \\
\text { - Develop transportation } \\
\text { infrastructure }\end{array}$ \\
\hline Competitiveness & $\begin{array}{l}\text { Improve the city's management and administration } \\
\text { - Raise administrative efficiency, secure } \\
\text { public involvement in resolving city affairs } \\
\text { - Strengthen the standing of Prague } \\
\text { within national public administration }\end{array}$ & $\begin{array}{l}\text { Establish a favourable business climate } \\
\text { - Eliminate constraints on business } \\
\text { - Reduce the tax burden } \\
\text { - Develop the real-estate market; reform } \\
\text { city-planning regulation } \\
\text { - Develop the labour market; improve } \\
\text { labour mobility; provide conditions } \\
\text { for retraining and upgrading skills } \\
\text { - Reorient financial resources towards } \\
\text { investment in the real economy }\end{array}$ & $\begin{array}{l}\text { Increase the competitiveness } \\
\text { of Vilnius } \\
\text { - Strengthen its significance } \\
\text { as a capital and strategically } \\
\text { attractive centre } \\
\text { - Build an image of Vilnius } \\
\text { as a knowledge economy } \\
\text { - Improve the urban image } \\
\text { of the city and make wider } \\
\text { use of its distinctiveness }\end{array}$ \\
\hline Economy & $\begin{array}{l}\text { Become a successful and competitive city with } \\
\text { a prosperous economy } \\
\text { - Utilise the city's potential to secure } \\
\text { competitive economy and prosperity } \\
\text { - Develop Prague as an important part } \\
\text { of the new Europe } \\
\text { - Secure economic activity according } \\
\text { to the potential of the city }\end{array}$ & $\begin{array}{l}\text { Integration into the world economy } \\
\text { - Strengthen foreign-trade and } \\
\text { transport functions } \\
\text { - Consolidate competitive } \\
\text { manufacturing industries } \\
\text { - Promote St. Petersburg on the } \\
\text { cultural and tourism markets } \\
\text { - Develop science, education } \\
\text { and innovation activities }\end{array}$ & $\begin{array}{l}\text { Develop a new economy } \\
\text { - Create favourable } \\
\text { conditions for the deve- } \\
\text { lopment of a knowledge } \\
\text { economy } \\
\text { - Ensure a favourable } \\
\text { environment for business } \\
\text { and investment }\end{array}$ \\
\hline
\end{tabular}

\section{Establish a favourable social environment}

Improve quality of life and become an attractive and well-balanced community

Society/residents' wellbeing
- Strengthen Prague's traditional position as a centre of education and culture

- Improve housing

- Promote safety
- Establish a stable social environment

- Develop the educational, cultural and intellectual potential of St. Petersburg's citizens

- Accelerate resolution of the housing problem, reform housing maintenance

- Restructure management of public transport and road maintenance

- Improve the quality of city and regional administration
Create a high-quality urban environment while respecting sustainable development; modernise transport infrastructure

- Gradually improve all areas of the city environment

Urban environment
- Sustainability of energy and material flows

- Development that respects cultural and historic heritage

- Create an attractive integrated system of public transit

- A reliable drinking-water system
Improve the urban environment

- Revive the historical city centre

- Form zones of dynamic urban redevelopment

- Develop the inner-city and suburban transport network and major roads

- Develop utility infrastructure

- Improve the state of the environment
Develop transportation infrastructure

- Ensure good international and external transport connections

- Ensure balanced development of the city's transportation system

- Modernise the engineering supply 
Table 3: (continued)

\begin{tabular}{|c|c|c|}
\hline & Sofia & Riga \\
\hline Major goals/priorities & $\begin{array}{l}\text { - Improve the competitiveness of the city's economy } \\
\text { - Invest and improve city services (infrastructure and social } \\
\text { programs) } \\
\text { - Enhance the quality of the built environment } \\
\text { - Improve city management and finances }\end{array}$ & $\begin{array}{l}\text { - Create a society that is educated and skilled, and } \\
\text { that respects culture } \\
\text { - Promote strong local communities within the city } \\
\text { - Promote an economy that uses east-west links }\end{array}$ \\
\hline
\end{tabular}

Improve city finances \& management
- Enable the city to make reliable financial forecasts and plan-
ning by establishing a stable and predictable system of in-
ter-governmental fiscal relations
- Improve the organisation of the municipal administration
- Enhance internal efficiency
- Improve communications with and response to citizens

\begin{tabular}{ll}
\hline $\begin{array}{l}\text { Improve the competitiveness } \\
\text { of the city's economy }\end{array}$ & $\begin{array}{l}\text { Promote an economy that } \\
\text { uses east-west links }\end{array}$ \\
$\begin{array}{ll}\text { - Sustain economic growth by creating a favourable business } \\
\text { climate }\end{array}$ & $\begin{array}{l}\text { - Promote and create international relations } \\
\text { - Broaden the economic base }\end{array}$ \\
- Capitalise on the city's human resources & - Develop service exports in Riga \\
- Form partnerships to support the local economy & - Develop transit infrastructure \\
\hline
\end{tabular}

\begin{tabular}{|c|c|c|}
\hline \multirow{7}{*}{$\begin{array}{l}\text { Society/residents' } \\
\text { wellbeing }\end{array}$} & \multirow[b]{2}{*}{ Improve city services } & \multirow{2}{*}{$\begin{array}{l}\text { Create a society that is educated } \\
\text { and skilled, and that respects culture } \\
\text { - Develop basic skills }\end{array}$} \\
\hline & & \\
\hline & \multirow{2}{*}{$\begin{array}{l}\text { - Invest in infrastructure to improve the quality of services: } \\
\text { district heating; water and sewerage; urban transport }\end{array}$} & - Follow market demands and changes; \\
\hline & & - Develop the knowledge-based economy \\
\hline & \multirow[t]{3}{*}{ - Improve social services: healthcare, education, social assistance } & - Commercialise scientific ideas \\
\hline & & - Promote professional higher education \\
\hline & & - Promote the exact sciences \\
\hline \multirow{6}{*}{ Urban environment } & Improve the built environment & Promote strong local communities \\
\hline & $\begin{array}{l}\text { - Create a balanced spatial structure to enhance sustainable } \\
\text { opportunities }\end{array}$ & - Create multifunctional neighbourhoods with \\
\hline & - Sustain the vitality of the city centre & \\
\hline & - Regenerate existing secondary centres & • Revitalise rundown areas \\
\hline & - Improve quality of life in existing housing areas & $\begin{array}{l}\text { - Promote neighbourhood identity and socially inte- } \\
\text { grated neighbourhoods }\end{array}$ \\
\hline & - Promote sustainable use of environmental resources & - Sustainable neighbourhood development \\
\hline
\end{tabular}

Source: Analysis of strategic plans by the author.

also Doytchinov, 2004); c) improving the quality of life in existing urban centres and residential areas (St Petersburg, Riga and Prague; see, e.g., also Csanádi et al., 2010) and d) promoting sustainable use of environmental resources (Prague and Sofia). In a similar fashion, the goals of a more efficient and effective transport system support a cluster of actions and programs in Riga, Vilnius and Prague. ${ }^{[10]}$

It is beyond the scope of this paper to provide detailed content analysis of the wide range of actions and programs in each thematic cluster. Although at times the links are not straightforward, the plans demonstrate relatively clear relationships between existing strengths and opportunities in the SWOT analysis and the strategic goals and objectives endorsed in the plans (City Development Authority of Prague, 2000). The typical hierarchical structure of the goals-achievement matrix is perhaps best illustrated in the strategic plans of Vilnius, Prague and St Petersburg. The action plans further delineate practical measures and specific timelines for their implementation to achieve the goals. 


\section{Conclusion: Venturing into the unknown territory of strategic spatial planning}

Planning for the uncertain future is a very important aspect of present post-communist politics and a valuable source of learning. It has obvious relevance to planners and policymakers attempting to apply standard policy options, successful plans and institutional structures drawn from Western Europe or elsewhere to transition countries. Although there are obvious differences in the way the three aspects of the transition process - the transition to democracy, a market economy and democratic governance - affect post-communist cities, they establish a very different and perhaps unique context for strategic planning. The magnitude of change, both in the external and internal environment, as well as the turbulence affecting planning institutions, is much more significant. This obvious complexity creates unique challenges for planners, making the traditional links between past, present and future less explicit and predictable.

In their search for new planning paradigms and more flexible approaches to city planning, municipalities in post-communist cities have embraced strategic planning as a way to involve residents, the business community and various stakeholders in defining a vision for the future. Drawing on the experience of six capital cities - Prague, St Petersburg, Vilnius, Sofia, Budapest and Riga - the research outlines the essential characteristics of the process (planning) and the product (a strategic plan). Using a framework for strategic spatial planning in the context of rapid economic, social and governance change, the research evaluates the results of the process, focusing on "what" and "how" in the complex reality of planning. The framework applies the traditional strategic planning model, which establishes relationships between the past, present and future to design alternative strategies for plan implementation, but in a much less stable and predictable institutional environment.

The strategic spatial planning process does not follow a well-established trajectory, but generally incorporates the following stages: a) scanning the environment, b) selecting key issues, c) setting mission statements or broad goals, d) carrying out external and internal analyses, e) developing goals, objectives and strategies with respect to each issue, f) developing an implementation plan to carry out strategic actions, and g) monitoring and updating the situation (Kaufman \& Jacobs, 1987; Albrechts et al., 2001). A key feature of the strategic spatial plan is the SWOT analysis as a basis for devising action strategies to achieve goals and objectives in priority areas. Another distinguishing characteristic feature is its orientation towards action, implementation and results. The institutional capacity to collaborate during the strategic planning process is perceived to increase the effectiveness of implementation. This institutionalisation (the design of arenas) could be initiated during the strategic planning process by a planning team, which may fuel forums for dialogue, decision-making and collaboration. John Bryson et al. (1986) distinguish three different strategic planning arenas: those for key decision-makers, the strategic planning team and strategic issue taskforces. The formal arenas could be complemented with informal ones in which new people, new alliances, new networks and new ideas are brought together to articulate strategic priorities and approaches (Albrechts et al., 2001).

In the absence of literature on planning in the transition countries in general and on strategic planning in particular, insights from these experiences might contribute to better understanding of urban transformation in post-communist cities and the complex reality of planning. In this context, the SWOT analysis may be more important as a way of establishing critical links between the past, present and future. Although this technical, rational approach might have its limitations, it is essential in establishing the framework for the participatory stages in the strategic planning process. Furthermore, the institutionalisation of strategic planning might be even more demanding if extensive consultation is envisioned to establish legitimacy, representation and diversity of input. Planning practice in post-communist cities is influenced by extensive reliance on physical land-use planning and experiences with public consultation tend to be limited. These are significant limitations for the design of the strategic planning process.

The strategic planning processes in these six cities have created a shared vision for the future of the city as well as a framework for more effectively planning policies and investments. The process itself provides a basis for interdepartmental coordination and the creation of strategic partnerships and alliances with central government, business and NGOs. Its goal-focused development priorities link economic, social, spatial and financial objectives, making some of the immediate choices on strategic priorities explicit. Stakeholder participation in the strategic process is "a search for a common vision" and aims to develop public ownership and support.

In thinking about some of the advantages and disadvantages of the process, several issues need to be considered. First, the selection of strategic goals capitalises on the advantage of hierarchical arrangements in strategic planning and strong leadership, which allows goals to be established at the top level (particularly in St Petersburg, Sofia and Vilnius) and developed into more detailed policies and implementation strategies at lower levels. Second, the process allows consideration of alternatives on the basis of substantial analytical work 
(SWOT) and the creation of a framework for more integrated decision-making in a collaborative manner (Vilnius, Prague and Sofia). Third, it establishes better and more transparent relationships among municipal bureaucrats, politicians and their constituencies (Budapest, St Petersburg and Prague). The institutional setup and task-specific circles, or thematic committees, bring together formal and informal institutions with experts taking the lead role and facilitate partnerships. Despite these advantages, the participatory process faces challenges and risks. It generates an enormous amount of information, which is not always consistent (Budapest, Riga and Sofia). It is difficult to achieve consensus and broker different interests, particularly at the level of action plans and budgets. Mutual trust, inclusiveness and partnership are critical for the legitimacy of the participatory process, but they take a long time to develop and nurture.

Although this article does not provide detailed content analysis of the range of actions and programs in each thematic cluster, it highlights similarities and differences of priorities in three domains: the economic, social and built environment. Cities have capitalised on their unique advantages as well as on strengths and opportunities in the SWOT analysis to define the strategic goals and objectives endorsed in the plans. The typical hierarchical structure of the goal-achievement matrix is perhaps best illustrated in the strategic plans of Vilnius, Prague and St Petersburg. The extent to which strategic planning has been embedded in the repertoire of instruments for urban management tends to be different. Prague and Vilnius have continued to regularly update action plans aligned with capital budgets, whereas in the other cities the sustainability of strategic planning efforts is less explicit (Riga and Sofia) and even non-existent (Budapest and St Petersburg). The critical difference is affecting the way strategic planning is institutionalised in the ex-post stage, with Vilnius and Prague setting up designated departments to monitor implementation and to augment action plans, if needed.

These experiments with strategic planning offer a systematic test of the effectiveness and appropriateness of the concept in post-communist cities. A few important elements might characterise a successful approach. First, strategic spatial planning in which the participatory planning process is equally important as the plan itself ensures broader consensus on priorities and also mobilises public and institutional support for its implementation. Second, it makes possible a combination of multiple priorities and objectives (e.g., economic growth, improvement of the business environment and social services, land-use planning and investment links), which is essential for creating cities that are competitive and liveable. Third, well-targeted strategic spatial plans with clearly established priorities allow synergies of various sectoral projects and generate posi- tive economic and social spillover effects. To sum up, it can be argued that strategic spatial planning is an efficient tool for managing post-communist cities. It creates opportunities to mobilise funds and wider support for cities' priorities and to define contextually appropriate multidimensional strategies for future development.

\section{Sasha Tsenkova}

University of Calgary, Faculty of Environmental Design, Calgary,

Canada

E-mail: tsenkova@ucalgary.ca

\section{Notes}

[1] For example, the Canadian International Agency supported the development of the "first generation" of strategic plans in Riga, Tallinn and Vilnius. More recently, the Cities Alliance - a global program led by the World Bank and the United Nations Centre for Human Settlements (UNCHS) - has played a critical role in the strategic planning processes of Sofia and Riga.

[2] The Budapest Concept defines three different planning periods: a medium-term (7-year) financial forecast and development plan; a long-term (15-year) program and 30- to 40-year very long-term vision (City of Budapest, 2003).

[3] Public consultation is facilitated by experts with participation open to everyone interested in the issues. Normally the agenda and the venue will be advertised widely; forms of engagement range from open discussion, professional presentations, posters and responses to questions from stakeholders.

${ }^{[4]}$ In St Petersburg a General Council and Executive Committee were appointed to work together with the Project Office at the Leontief Centre.

[5] Prague had a participatory process that established a forum for the public to actively engage in preparing the strategic vision and proposals for its implementation.

[6] The campaign addressed a major problem with the lack of interest demonstrated at the beginning of the strategic planning process; only six opinions were received in the official public consultation.

[7] The Vilnius City Strategic Plan process included 15 working breakfasts with 300 participants, six seminars with more than 400 participants and two conferences. In addition, the plan received suggestions from more than 100 residents of Vilnius (Vilnius City Municipality Administration, 2003).

${ }^{[8]}$ The conference attracted 400 people in its thematic sessions. This was followed by six half-day discussions in the districts of Budapest with the participation of political leaders (mayor or deputy mayor, head of planning committee) and chief architects (Tosics, 2003).

[9] In the case of Budapest, the main differences between experts and city politicians became visible 2 years after the first draft of the plan. The politicians wanted to see more financial analysis behind the suggested programs as well as a more precise definition of the role of the municipality and other stakeholders in city development (Tosics, 2003).

[10] Urban development in the 1990s in most of the post-communist world, particularly in the capital cities, has been characterised by 
suburbanisation of housing, retail and jobs. These trends, together with growing car ownership, have created immense transportation challenges in the historic cities (for further discussion, see Tsenkova \& Nedovic-Budic, 2006).

\section{Acknowledgements}

An earlier version of this paper was published in The post-socialist city. Urban form and space transformation in Central and Eastern Europe after socialism. Special thanks to Dalia Bardauskienè, Advisor to the Mayor on Strategic Planning in Vilnius, to Andis Kublačovs, Head of the Development Plans Management Unit in Riga, and to Milan Turba, Director for Strategic Planning, City Development Authority, Prague for their input, guidance and kind assistance with the research. I am particularly grateful to municipal staff for their efficient and professional collaboration while I was leading the Sofia strategic planning process.

\section{References}

Abott, J. (2005) Understanding and managing the unknown. The nature of uncertainty in planning. Journal of Planning Education and Research, 24(3), pp. 237-251. DOI: 10.1177/0739456X04267710

Adair, A., Berry, J., McGreal, S., Sykora, A., Ghanbari Parsa, A. \& Redding, B. (1999) Globalisation of real estate markets in Central Europe. European Planning Studies, 7(3), pp. 295-305.

Albrechts, L. (2006) Shifts in strategic spatial planning? Some evidence from Europe and Australia. Environment and Planning A, 38(6), pp. 1149-1170. DOI: 10.1068/a37304

Albrechts, L., Alden, J. \& da Rosa Pires, A. (eds.) (2001) The changing institutional landscape of planning. Aldershot, Ashgate.

Albrechts, L., Healey, P. \& Kunzman, K. (2003) Strategic spatial planning and regional governance in Europe. APA Journal, 69(2), pp. 113-129.

Andrusz, G., Harloe, M. \& Szelenyi, I. (eds.) (1996) Cities after socialism. Oxford, Blackwell Publishers Inc.

Baker, M. (2001) Some reflections on strategic planning processes in three urban regions. Planning Theory and Practice, 2(2), pp. 230-235. DOI: 10.1080/14649350120068849

Bater, J. H. (2001) Adjusting to change: Privilege and place in post-Soviet central Moscow. Canadian Geographer, 45(2), pp. $237-$ 251. DOI: 10.1111/j.1541-0064.2001.tb01486.x

Bertaud, A. \& Renaud, B. (1997) Socialist cities without land markets. Journal of Urban Economics, 41(1), pp. 137-151. DOI: 10.1006/ juec.1996.1097

Bruton, M. J. \& Nicholson, D. J. (1985) Strategic land use planning and the British development plan system. Town Planning Review, 56(1), pp. 21-41.

Bryson, J., Freeman, E. \& Roening, W. (1986) Strategic planning in the public sector: approaches and directions. In: Checkoway, B. (ed.) Strategic perspectives on planning practice, pp. 66-85. Lexington, Lexington Books.

Buck, N., Gordon, J., Harding, A. \& Turok, I. (eds.) (2005) Changing cities. Rethinking urban competitiveness cohesion and governance. Hampshire, Palgrave Macmillan.

Buckley, R. \& Mini, F. (2000) From commissars to mayors: Cities in the transition economies. Washington, DC, World Bank.

Buckley, R. \& Tsenkova, S. (2001) Sofia city development strategy. Preliminary assessment. Washington, DC, World Bank.

City Development Authority of Prague (2000) Strategic plan of the city of Prague. Prague.

City Development Authority of Prague (2009) Programme for the implementation of Prague strategic plan for 2009-2015 period. Prague.

City of Budapest (2003) Strategic development concept for Budapest. Budapest.

Csanádi, G., Csizmady, A. \& Olt, G. (2010) Najnovejše smeri razvoja urbane prenove $v$ Budimpešti [Recent trends in urban renewal in Budapest]. Urbani izziv, 21(1), pp. 42-50 [117-125]. DOI: 10.5379/ urbani-izziv-en-2010-21-01-004

Doytchinov, G. (2004) Sofija - mesto priložnosti, mesto diskontinuuma [Sofia - a city of potentials, a city in a discontinuum]. Urbani izziv, 15(2), pp. 25-31 [117-120]. DOI: 10.5379/urbani-izziven-2004-15-02-003

Egedy, T. \& Kovács, Z. (2010) Budimpešta, mesto kot nalašč za razvoj kreativne industrije? [Budapest: A great place for creative industry development?]. Urbani izziv, 21(2), pp. 58-68 [127-138]. DOI: 10.5379/urbani-izziv-en-2010-21-02-006

European Commission (2007) The urban audit. Brussels.

Faludi, A. (2004) Unfinished business: European spatial planning in the 2000s. Town Planning Review, 74(1), pp. 121-140. DOI: 10.3828/ tpr.74.1.7

Friedman, J. (1987) Planning in the public domain: From knowledge to action. Princeton, NJ, Princeton University Press.

General Council for St Petersburg (1998) Strategic plan for St Petersburg. St Petersburg.

Golubchikov, O. (2004) Urban planning in Russia: Towards the market. European Planning Studies, 12(2), pp. 229-247. DOI: 10.1080/0965431042000183950

Hamilton, F. E. I., Andrews, K. D. \& Pichler-Milanovic, N. (eds.) (2005) Transformations of cities in Central and Eastern Europe: Towards globalisation. Tokyo, United Nations University Press.

Healey, P., Khakee, A., Motte, A. \& Needham, B. (1997) (eds.) Making strategic spatial plans: Innovation in Europe. London, University College London Press.

Healey, P., Khakee, A., Motte, A. \& Needham, B. (1999) European developments in strategic spatial planning. European Planning Studies, 7(3), pp. 339-355. DOI: 10.1080/09654319908720522

Jaakson, R. (2000) Supra-national spatial planning of the Baltic Sea region and competing narratives for tourism. European Planning Studies, 8(5), pp. 565-579. DOI: 10.1080/713666424

Kaufman, J. L. \& Jacobs, H. M. (1987) A public perspective on strategic planning. Journal of the American Planning Association, 53(1), pp. 23-33. DOI: $10.1080 / 01944368708976632$

Maier, K. (2000) The role of strategic planning in the development 
of Czech towns and regions. Planning Practice and Research, 15(3), pp. 247-255. DOI: 10.1080/713691901

Mintzberg, H. (1994) The rise and fall of strategic planning: Reconceiving roles for planning. New York, The Free Press.

Nedovic-Budic, Z. (2001) Adjustment of planning practice to the new Eastern and Central European context. Journal of the American Planning Association, 67(1), pp. 38-52. DOI: 10.1080/01944360108976354

Newman, P. \& Thornley, A. (1996) Urban planning in Europe: International competition, national systems \& planning projects. London, Routledge.

Radford, K. J. (1980) Strategic planning: An analytical approach. Reston, VA, Reston Publishing Co. Inc.

Riga City Council (2005) Riga city development strategy 2006-2018. Riga.

Salet, W. \& Faludi, A. (2000) (eds.) The revival of strategic planning. Amsterdam, Edita KNAW.

Stanilov, K. (2007) (ed.) The post-socialist city. Urban form and space transformation in Central and Eastern Europe after socialism. Dortmuth, Springer.

Thomas, M. (1998) Thinking about planning in the transitional countries of Central and Eastern Europe. International Planning Studies, vol. 3(3), pp. 321-331. DOI: 10.1080/13563479808721717

Tosics, I. (2003) A new tool for consultants to influence policy-making? Strategic planning in European cities. Paper presented at the European Urban Development, Research and Policy: The Future of European Cohesion Policy, 28-30 August, Budapest, Hungary. Typescript.

Tsenkova, S. (2002) SWOT analysis of Sofia's economy, infrastructure and spatial planning issues. Washington, DC, World Bank.

Tsenkova, S. (2006) Beyond transitions: Understanding urban change in post-socialist cities. In: Tsenkova, S. \& Budic-Nedovic, Z. (eds.) The urban mosaic of post-socialist Europe, pp. 21-50. Heidelberg, Physica-Verlag. DOI 10.1007/3-7908-1727-9_2

Tsenkova, S. (2007a) Urban futures: Strategic planning in post-socialist Europe. In: Stanilov, K. (ed.) The post-socialist city: Urban form and space transformation in Central and Eastern Europe after socialism, pp. 447-471. Dordrecht, Springer.

Tsenkova, S. (2007b) Reinventing strategic planning in post-socialist cities: Experiences from Sofia. European Planning Studies, 15(3), pp. 295-317. DOI: 10.1080/09654310601017133

Tsenkova, S. (2008) The comeback of post-socialist cities. Urban Research and Practice, 1(3), pp. 291-310. DOI: 10.1080/17535060802476525

Tsenkova, S. \& Nedovic-Budic, Z. (eds.) (2006) The urban mosaic of post-socialist Europe. Heidelberg, Physica-Verlag.

Van Kempen, R., Vermeulen, M. \& Baan, A. (eds.) (2005) Urban issues and urban policies in the new EU countries. Aldershot, Ashgate.

Vilnius City Municipality Administration (2003) Vilnius city strategic plan 2002-2011. Vilnius.
World Bank (2000) Cities in transition: World Bank urban and local government strategy. Washington, DC.

Zeijlon, A., Tsenkova, S. \& Ionkova, K. (2002) Sofia development strategy. Washington, DC, World Bank, Municipality of Sofia. 